\title{
Food intolerance in rheumatoid arthritis. I. A double blind, controlled trial of the clinical effects of elimination of milk allergens and azo dyes
}

\author{
M A F J van de Laar, J K van der Korst
}

\begin{abstract}
The hypothetically negative influence of food on the clinical activity of seropositive rheumatoid arthritis was studied using two types of artificial elementary food. One diet was allergen free, the other allergen restricted, containing only lactoproteins and yellow dyes. Ninety four patients entered the study, which lasted 12 weeks. During the second four week period they were randomly assigned to one of the two artificial foods. Comparison between baseline and subsequent periods showed only subjective improvements. No differences were seen between the clinical effects of the two tested diets. Nine patients (three in the allergen restricted group, six in the allergen free group) showed favourable responses, followed by marked disease exacerbation during rechallenge. Dietary manipulation also brought about changes in objective disease activity parameters in these patients. The existence of a subgroup of patients in whom food intolerance influences the activity of rheumatoid factor seropositive rheumatoid arthritis deserves serious consideration.
\end{abstract}

It is a common belief among patients with rheumatoid arthritis (RA) that certain foods or food ingredients have a negative influence on the activity of their disease. Allergy is often incriminated, though to date evidence for this has been scanty. In only a few patients has allergy for lactoproteins, ${ }^{1-3}$ corn, ${ }^{4}$ or cereals ${ }^{5}$ been substantiated as a probable aggravating factor. Studies in which groups of patients with RA were given allergen restricted diets have shown conflicting results. ${ }^{6-11}$

The availability of low molecular, artificial food makes it possible to investigate the role of various foodstuffs. Two common and often incriminated items, lactoproteins and azo dyes, were studied in a double blind, randomised trial in active rheumatoid factor positive RA.

\section{Patients and methods}

PATIENTS

Patients were eligible if they fulfilled at least six American Rheumatology Association criteria for RA, ${ }^{12}$ including a positive rheumatoid factor test. In all cases disease onset occurred after the age of 16 and there was no medical indication for any dietary restriction. Patients in functional class 4 according to Steinbrocker were ex- cluded. ${ }^{13}$ Disease activity was substantiated by the presence of at least three of the four following criteria: $(a)$ erythrocyte sedimentation rate $\geqslant 28 \mathrm{~mm} / \mathrm{h} ;(b)$ morning stiffness $\geqslant 45$ minutes; (c) more than five tender joints; and $(d)$ more than two swollen joints. Only those patients who were still motivated to participate after a preliminary trial of the experimental diet entered the study. Drug treatment was held constant during the study. All disease modifying drugs were used in constant dosages for at least three months before the start of the study. Corticosteroids were allowed in doses not exceeding the equivalent of prednisone $10 \mathrm{mg} /$ day.

In January 1988 the outpatient department of rheumatology of the Jan van Breemen Instituut had records of 1042 patients with rheumatoid factor positive RA. Two hundred and forty two patients were considered by their rheumatologist to be ineligible for participation, for a variety of reasons. Eight hundred patients were contacted by letter. Extensive information about the aims and the content of the study was given, and they were invited to participate. Two hundred and thirty two patients were available for an intake investigation. One hundred and sixteen patients conformed to all entrance criteria.

\section{EXPERIMENTAL DIET}

The two diets were both artificial food, which supplied all nutritional requirements. The first was free from all potentially allergenic components, additives, and preservatives (Pepti 2000; Nutricia, Zoetermeer, The Netherlands) (table 1). The second contained milk allergens and azo colourings, and was free from other potentially allergenic materials, additives, and preservatives (Nutrison; Nutricia) (table 1). Both powdered feedings were provided in tins of $90 \mathrm{~g}$, with a double blind code. The patients were supplied with five different coded flavourings. These flavourings were either allergen free or contained azo dyes, in accordance with the experimental diet. The dietician interviewed each patient and calculated the individual daily energy intake. The recommended amount of daily, experimental food was based on these calculations. No other foods were allowed beyond three apples a day, tea, allergen free chewing gum, and sugar. To obtain maximum patient compliance the dietician gave each patient extensive instructions. Each patient was further provided with a five page instruction Dr Jan van Breemenstraat 2 1056 AB Amsterdam

Accepted for publication 14 May 1991 
Table 1 Compositions of diets

\begin{tabular}{|c|c|c|c|}
\hline \multirow{2}{*}{\multicolumn{4}{|c|}{ 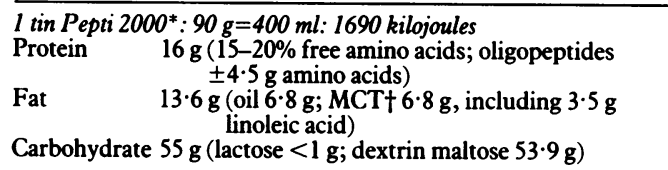 }} \\
\hline & & & \\
\hline $\begin{array}{l}\mathrm{Ca} \\
\mathrm{P} \\
\mathrm{Fe} \\
\mathrm{Na} \\
\mathrm{K} \\
\mathrm{Cl} \\
\mathrm{I} \\
\mathrm{Zn} \\
\mathrm{Mg} \\
\mathrm{Mn} \\
\mathrm{Cu}\end{array}$ & $\begin{array}{r}185 \mathrm{mg} \\
145 \mathrm{mg} \\
4 \mathrm{mg} \\
185 \mathrm{mg} \\
560 \mathrm{mg} \\
345 \mathrm{mg} \\
24 \mu \mathrm{g} \\
2.8 \mathrm{mg} \\
60 \mathrm{mg} \\
1.6 \mathrm{mg} \\
0.4 \mathrm{mg}\end{array}$ & $\begin{array}{l}\text { Vitamin A } \\
\text { Vitamin B-1 } \\
\text { Vitamin B-2 } \\
\text { Vitamin B-6 } \\
\text { Vitamin B-12 } \\
\text { Vitamin C } \\
\text { Vitamin D } \\
\text { Vitamin E } \\
\text { Folic acid } \\
\text { Niacin } \\
\text { Pantotheic acid } \\
\text { Biotin } \\
\text { Inositol } \\
\text { Choline }\end{array}$ & $\begin{array}{c}0.3 \mathrm{mg} \\
0.3 \mathrm{mg} \\
0.4 \mathrm{mg} \\
0.4 \mathrm{mg} \\
0.8 \mu \mathrm{g} \\
22 \mathrm{mg} \\
2 \mu \mathrm{g} \\
3.6 \mathrm{mg} \\
100 \mu \mathrm{g} \\
4 \mathrm{mg} \\
2 \mathrm{mg} \\
60 \mu \mathrm{g} \\
90 \mathrm{mg} \\
180 \mathrm{mg}\end{array}$ \\
\hline \multicolumn{4}{|c|}{$\begin{array}{l}\text { Itin Nutrison* }: 90 \mathrm{~g}=400 \mathrm{ml}: 1690 \text { kilojoules } \\
\text { Protein } 20.25 \mathrm{~g} \text { (lactoproteins) } \\
\text { Fat } 16 \mathrm{~g} \text { (oil } 16 \mathrm{~g} \text {; including } 4.8 \mathrm{~g} \text { linoleic acid) } \\
\text { Carbohydrate } 48 \mathrm{~g} \text { (lactose }<1 \mathrm{~g} \text {; dextrin maltose } 46.4 \mathrm{~g} \text {; } \\
\text { others } 1.6 \mathrm{~g} \text { ) }\end{array}$} \\
\hline $\begin{array}{l}\mathrm{Ca} \\
\mathrm{P} \\
\mathrm{Fe} \\
\mathrm{Na} \\
\mathrm{K} \\
\mathrm{Cl} \\
\mathrm{I} \\
\mathrm{Zn} \\
\mathrm{Mg} \\
\mathrm{Mn} \\
\mathrm{Cu}\end{array}$ & $\begin{array}{r}243 \mathrm{mg} \\
252 \mathrm{mg} \\
52 \mathrm{mg} \\
252 \mathrm{mg} \\
630 \mathrm{mg} \\
405 \mathrm{mg} \\
27 \mu \mathrm{\mu g} \\
3 \mathrm{mg} \\
40.5 \mathrm{mg} \\
1.7 \mathrm{mg} \\
0.5 \mathrm{mg}\end{array}$ & $\begin{array}{l}\text { Vitamin A } \\
\text { Vitamin B-1 } \\
\text { Vitamin B-2 } \\
\text { Vitamin B-6 } \\
\text { Vitamin B-12 } \\
\text { Vitamin C } \\
\text { Vitamin D } \\
\text { Vitamin E } \\
\text { Folic acid } \\
\text { Niacin } \\
\text { Pantotheic acid } \\
\text { Biotin } \\
\text { Inositol } \\
\text { Choline }\end{array}$ & $\begin{array}{c}0.3 \mathrm{mg} \\
0.3 \mathrm{mg} \\
0.4 \mathrm{mg} \\
0.4 \mathrm{mg} \\
0.8 \mu \mathrm{g} \\
22 \mathrm{mg} \\
2.1 \mu \mathrm{g} \\
3.8 \mathrm{mg} \\
90 \mu \mathrm{g} \\
3.9 \mathrm{mg} \\
1.9 \mathrm{mg} \\
63 \mu \mathrm{g} \\
90 \mathrm{mg} \\
180 \mathrm{mg}\end{array}$ \\
\hline
\end{tabular}

${ }^{*}$ From Nutricia, Zoetermeer, The Netherlands.

†MCT $=$ medium chain triglycerides.

booklet and the telephone numbers of the dietician and the investigator. Unscheduled telephone calls were made by the dietician. ${ }^{14}$ is

\section{STUDY DESIGN}

The double blind, randomised study was carried out over a period of 12 weeks. During the first four weeks patients followed their usual diets (baseline). During the second four week period each patient used one of the two diets described above (diet). For the remaining four weeks patients returned to their usual diets (rechallenge). Clinical and laboratory parameters of disease activity were scored every two weeks, always at the same time of day by the same blind observer. Duration of morning stiffness was assessed in minutes from time of rising until maximum improvement (maximum 180). Global assessment and fatigue were both scored on a 10 point visual analogue scale. Body weight was measured to the nearest $0.1 \mathrm{~kg}$. The number of tender joints on pressure or motion (maximum 77) and the number of swollen joints (maximum 74) were recorded. Pain was scored according to Ritchie (maximum 78) ${ }^{16}$ Bilateral grip strength $(\mathrm{mmHg})$ was measured with a vigorimeter. The 30 feet $(9 \cdot 1 \mathrm{~m})$ walking time was measured to the nearest 0.1 second. The following laboratory parameters were also measured: erythrocyte sedimentation rate $(\mathrm{mm} / \mathrm{h})$, haemoglobin concentration $(\mathrm{g} / \mathrm{l})$, thrombocytes $\left(10^{9} / \mathrm{l}\right)$, leucocytes $\left(10^{9} / 1\right)$, eosinophils (\%), C reactive protein (mg/l), and IgM rheumatoid factor (IU/l).

ETHICS

The approval of the medical ethical committee of the medical faculty of the University of
Amsterdam was obtained. The patients gave informed consent.

\section{STATISTICS}

Statistical analysis was carried out with the SPSS PC + V3.0 software package. Differences between groups were tested with independent $t$ tests or Mann-Whitney Wilcoxon rank tests. Differences between variables were tested using one way analysis of variance.

\section{Results}

One hundred and sixteen patients were selected and randomly assigned to one of two groups for the study. At the time of entrance, up to 10 months after intake, 16 patients were unable to start for various reasons unrelated to the study. In an additional six patients disease activity had declined below the level of the activity criteria. Ninety four patients entered the study (table 2). Of these, 13 were unable to comply with the diet. Two patients changed drug treatment and one fractured her hip. The 16 drop-outs were equally distributed between the two groups. Seventy eight patients completed the study according to the protocol. After disclosure of the coding the two groups proved to be comparable with respect to all entrance parameters (table 3).

Improvement in certain clinical and subjective disease activity parameters was noted for all patients taking part in the study during the four week diet period. The parameters for morning stiffness, tender joints, swollen joints, 'global assessment', the Ritchie index, and the 'fatigue score' improved significantly $(\mathrm{p}<0 \cdot 05)$. Other parameters also improved, but the difference did not reach significance. During the diet a mean weight loss of $2.7 \mathrm{~kg}$ (SD 1.8) was seen. No relevant effect of the experimental feeding was noted for any of the laboratory parameters during the four week diet period.

Table 2 Demographic and disease characteristics of the 94 patients who entered the study. Disease activity parameters are given as mean $(S D)$

\begin{tabular}{|c|c|c|}
\hline Characteristic & $\begin{array}{l}\text { Hypoallergic } \\
(n=49)\end{array}$ & $\begin{array}{l}\text { Allergen free } \\
(n=45)\end{array}$ \\
\hline $\begin{array}{l}\text { Sex female } \\
\text { Allergic history } \\
\text { Age (years) } \\
\text { Disease (years) }\end{array}$ & $\begin{array}{l}36(73 \%) \\
9(18 \%) \\
58.6 \\
10.6\end{array}$ & $\begin{array}{l}30(67 \%) \\
7(16 \%) \\
57 \cdot 7 \\
10 \cdot 8\end{array}$ \\
\hline $\begin{array}{l}\text { Drugs } \\
\text { NSAIDs* } \\
\text { Second line } \\
\text { Prednisone }\end{array}$ & $\begin{array}{c}43(88 \%) \\
34(69 \%) \\
2(4 \%)\end{array}$ & $\begin{array}{l}41(91 \%) \\
28(62 \%) \\
0\end{array}$ \\
\hline $\begin{array}{l}\text { Disease activity parameters } \\
\text { Morning stiffness }(\mathrm{min}) \\
\text { Tender joints } \\
\text { Swollen joints } \\
\text { Ritchie index } \\
\text { Grip strength left }(\mathrm{mmHg}) \\
\text { Grip strength right }(\mathrm{mmH}) \\
\text { Walking time } 30 \text { feet }(\mathrm{s}) \\
\text { Global assessment } \\
\text { Fatigue score } \\
\text { ESR* }(\mathrm{mm} / \mathrm{h}) \\
\text { Haemoglobin }(\mathrm{g} / \mathrm{l}) \\
\text { Leucocytes }\left(\times 10^{9} / \mathrm{l}\right) \\
\% \text { Eosinophils } \\
\text { Thrombocytes }\left(\times 10^{9} / 1\right) \\
\text { Body weight }(\mathrm{kg})\end{array}$ & $\begin{array}{c}75 \cdot 6(59 \cdot 6) \\
21 \cdot 1(12 \cdot 7) \\
7 \cdot 3(5 \cdot 8) \\
16 \cdot 2(8 \cdot 4) \\
23 \cdot 3(17 \cdot 7) \\
23 \cdot 6(14 \cdot 6) \\
10 \cdot 6(3 \cdot 6) \\
5 \cdot 1(1 \cdot 9) \\
5 \cdot 3(2 \cdot 1) \\
47 \cdot 2(24 \cdot 9) \\
126(14) \\
7 \cdot 4(2 \cdot 2) \\
2 \cdot 7(2 \cdot 6) \\
284(90) \\
69 \cdot 9(10 \cdot 4)\end{array}$ & $\begin{array}{c}71 \cdot 2(57 \cdot 5) \\
19 \cdot 4(10 \cdot 9) \\
5 \cdot 7(3 \cdot 1) \\
14 \cdot 4(7 \cdot 2) \\
24 \cdot 2(13.7) \\
23 \cdot 6(12 \cdot 6) \\
10 \cdot 7(4 \cdot 7) \\
5 \cdot 4(1 \cdot 6) \\
5 \cdot 3(2 \cdot 0) \\
39 \cdot 4(20 \cdot 2) \\
126(13) \\
7 \cdot 7(1 \cdot 6) \\
2 \cdot 4(2 \cdot 1) \\
300(102) \\
68 \cdot 2(10 \cdot 3)\end{array}$ \\
\hline
\end{tabular}

There were no significant differences between the groups for any parameter using the Mann-Whitney Wilcoxon rank test. *NSAID=non-steroidal anti-inflammatory drug; ESR= erythrocyte sedimentation rate. 
Table 3 Changes in disease activity parameters due to two different artificial foodstuffs. Results are given as mean (SD)

\begin{tabular}{|c|c|c|c|c|c|c|}
\hline \multirow[t]{2}{*}{ Parameter } & \multicolumn{3}{|l|}{ Diet $^{*}$} & \multicolumn{3}{|l|}{ Rechallenge ${ }^{*}$} \\
\hline & $\begin{array}{l}\text { Allergen free } \\
(n=38)\end{array}$ & $p$ Valuet & $\begin{array}{l}\text { Hypoallergic } \\
(n=40)\end{array}$ & $\begin{array}{l}\text { Allergen free } \\
(n=38)\end{array}$ & $p$ Value & $\begin{array}{l}\text { Hypoallergic } \\
(n=40)\end{array}$ \\
\hline $\begin{array}{l}\text { Morning stiffness (min) } \\
\text { Tender joints } \\
\text { Swollen joints } \\
\text { Ritchie index } \\
\text { Grip strength left (mmHg) } \\
\text { Grip strength right }(\mathrm{mmHg}) \\
\text { Walking time } 30 \text { feet }(\mathrm{s}) \\
\text { Global assessment } \\
\text { Fatigue score } \\
\text { ESR } ¥(\mathrm{~mm} / \mathrm{h}) \\
\text { CRP }(\mathrm{mg} / \mathrm{l}) \\
\text { Body weight }(\mathrm{kg})\end{array}$ & $\begin{array}{l}-23 \cdot 4(39 \cdot 1) \\
-3 \cdot 2(7 \cdot 7) \\
-0.9(3 \cdot 0) \\
-1 \cdot 9(6 \cdot 8) \\
+4 \cdot 4(7 \cdot 1) \\
+2 \cdot 5(9 \cdot 2) \\
-0.03(2 \cdot 0) \\
+0 \cdot 7(1 \cdot 3) \\
+0 \cdot 7(1 \cdot 3) \\
+2 \cdot 0(10 \cdot 9) \\
-1 \cdot 7(15 \cdot 7) \\
-2 \cdot 1(1 \cdot 4)\end{array}$ & $\begin{array}{l}\text { NS } \\
\text { NS } \\
\text { NS } \\
\text { NS } \\
\text { NS } \\
\text { NS } \\
\text { NS } \\
\text { NS } \\
\text { NS } \\
\text { NS } \\
\text { NS } \\
0.016\end{array}$ & $\begin{array}{l}-27 \cdot 3(38 \cdot 0) \\
-4 \cdot 1(9 \cdot 2) \\
-2 \cdot 2(3 \cdot 3) \\
-2 \cdot 0(6 \cdot 1) \\
+2 \cdot 7(7 \cdot 2) \\
+0 \cdot 8(6 \cdot 4) \\
-0 \cdot 39(2 \cdot 6) \\
+1 \cdot 1(1 \cdot 3) \\
+1 \cdot 1(1 \cdot 5) \\
+0 \cdot 2(6 \cdot 9) \\
-5 \cdot 5(12 \cdot 2) \\
-3 \cdot 2(2 \cdot 1)\end{array}$ & $\begin{array}{l}+8 \cdot 7(34 \cdot 7) \\
+5 \cdot 0(8 \cdot 5) \\
+0 \cdot 7(2 \cdot 8) \\
+3 \cdot 2(6 \cdot 8) \\
-4 \cdot 7(7 \cdot 5) \\
-2 \cdot 5(10 \cdot 2) \\
+0 \cdot 3(1 \cdot 5) \\
-1 \cdot 1(1 \cdot 6) \\
-0.7(1 \cdot 2) \\
-1 \cdot 3(11 \cdot 9) \\
+5 \cdot 3(27 \cdot 2) \\
+0.7(1 \cdot 1)\end{array}$ & $\begin{array}{l}\text { NS } \\
\text { NS } \\
\text { NS } \\
\text { NS } \\
\text { NS } \\
\text { NS } \\
\text { NS } \\
\text { NS } \\
\text { NS } \\
\text { NS } \\
\text { NS } \\
\text { NS }\end{array}$ & $\begin{array}{c}+14 \cdot 2(27 \cdot 7) \\
+2 \cdot 9(7 \cdot 3) \\
+1 \cdot 1(3 \cdot 3) \\
+2 \cdot 4(5 \cdot 7) \\
-1 \cdot 6(7 \cdot 9) \\
-1 \cdot 8(8 \cdot 0) \\
+0 \cdot 46(3 \cdot 1) \\
-0.9(1 \cdot 6) \\
-0 \cdot 4(1 \cdot 2) \\
+1 \cdot 6(10 \cdot 1) \\
+27 \cdot 2(131 \cdot 7) \\
1 \cdot 2(1 \cdot 2)\end{array}$ \\
\hline
\end{tabular}

${ }^{*}$ Diet-patients received one of the two diets described in table 1 ; rechallenge - the patients returned to their usual diets.

tp Values were calculated with Mann-Whitney Wilcoxon rank tests.

$\neq \mathrm{ESR}=$ erythrocyte sedimentation rate; $\mathrm{CRP}=\mathrm{C}$ reactive protein.

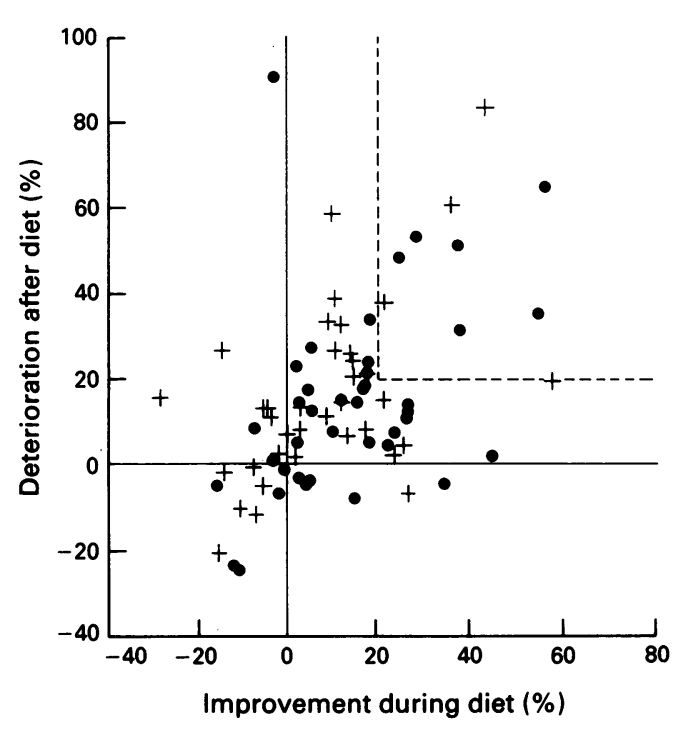

- Allergen free

+ Lactoprotein and azo dyes

Percentage of overall changes during and after artificial feeding. The scatter indicates an'overall improvement during diet $v$ overall deterioration during rechallenge. Overall changes are calculated as average of percentage change in (morning stiffness + tender joints + swollen joints + Ritchie index +walking time +erythrocyte sedimentation rate $+C$ reactive protein) and (bilateral grip strength + global assessment score +fatigue score). The dashed line encompasses the nine patients who seemed to show an unequivocal effect.
During the course of the rechallenge the change in clinical and subjective parameters was reversed, but only the increase in the number of tender joints and the regression of patients' global assessment was statistically significant. At the same time the mean body weight increased.

No significant differences in the effects of allergen free and allergen restricted diets could be established, except for the reduction in body weight (table 3 ).

The effects of both experimental artificial foods on the disease activity varied considerably among the patients. Rechallenging also resulted in widely varying changes in disease activity parameters. We selected nine patients in whom artificial feeding was accompanied by at least $20 \%$ improvement and rechallenging induced more than $20 \%$ deterioration (figure). These comprised three patients from the allergen restricted group and six from the allergen free group. It was found that these marked responders had shown greater disease activity during baseline observation and were, on average, considerably heavier than the other patients (table 4). After rechallenge, disease activity among the marked responders was also greater than it had been at the beginning of the study; whereas for the others disease activity was about the same at the end of the study as during baseline observation (table 4).

Table 4 Disease activity during baseline, at end of diet, and at end of rechallenge

\begin{tabular}{|c|c|c|c|c|c|c|}
\hline \multirow[t]{2}{*}{ Parameter } & \multicolumn{3}{|c|}{ Responders $(n=9)$} & \multicolumn{3}{|c|}{ Non-responders $(n=69)$} \\
\hline & Baseline & End of diet & End of rechallenge & Baseline & End of diet & End of rechallenge \\
\hline $\begin{array}{l}\text { Morning stiffness (min) } \\
\text { Tender joints } \\
\text { Swollen joints } \\
\text { Ritchie index } \\
\text { Grip strength left (mmHg) } \\
\text { Grip strength right (mmHg) } \\
\text { Walking time } 30 \text { feet (s) } \\
\text { Global assessment } \\
\text { Fatigue score } \\
\text { ESR (mm/h) } \\
\text { CRPS (mg/l) } \\
\text { IgM RFS (ELISA) S (IU/l) } \\
\text { Body weight (kg) }\end{array}$ & $\begin{array}{r}88 \cdot 7 \\
20 \cdot 9 \\
7 \cdot 3 \\
14 \cdot 9 \\
17 \cdot 7 \\
16 \cdot 6 \\
12 \cdot 0 \\
4 \cdot 6 \\
4 \cdot 8 \\
35 \cdot 9 \\
19 \cdot 1 \\
185 \\
77 \cdot 8\end{array}$ & $\begin{array}{r}43 \cdot 5 \\
8 \cdot 4 \\
4 \cdot 9 \\
6 \cdot 9 \\
25 \cdot 2 \\
22 \cdot 8 \\
9 \cdot 5 \\
7 \cdot 1 \\
7 \cdot 6 \\
36 \cdot 6 \\
13 \cdot 7 \\
154 \\
74 \cdot 9\end{array}$ & $\begin{array}{c}96 \cdot 7 \\
23 \cdot 2^{*} \ddagger \ddagger \\
9 \cdot 3 \\
18 \cdot 4^{*} \ddagger \ddagger \\
15 \cdot 2 \\
12 \cdot 4 \\
12 \cdot 4 \\
3 \cdot 2^{*} \dagger \ddagger \\
4 \cdot 6^{*} \ddagger \ddagger \\
38 \cdot 0 \\
25 \cdot 2 \\
199 \\
75 \cdot 8\end{array}$ & $\begin{array}{r}74 \cdot 7 \\
18 \cdot 8 \\
6 \cdot 1 \\
14 \cdot 3 \\
23 \cdot 9 \\
24 \cdot 7 \\
10 \cdot 1 \\
5 \cdot 1 \\
5 \cdot 4 \\
44 \cdot 1 \\
25 \cdot 4 \\
274 \\
68 \cdot 9\end{array}$ & $\begin{array}{r}55 \cdot 4 \\
16 \cdot 6 \\
4 \cdot 9 \\
13 \cdot 1 \\
25 \cdot 6 \\
25 \cdot 3 \\
9.9 \\
5 \cdot 5 \\
5 \cdot 9 \\
45 \cdot 5 \\
23 \cdot 2 \\
255 \\
66.3\end{array}$ & $\begin{array}{c}60 \cdot 6^{*} \\
19 \cdot 1 \\
5 \cdot 3^{*} \dagger \\
14 \cdot 8 \\
23 \cdot 4 \\
24 \cdot 3 \\
10 \cdot 0 \\
4 \cdot 9 \\
5 \cdot 7 \\
45 \cdot 6 \\
28 \cdot 4 \\
264 \\
67 \cdot 3\end{array}$ \\
\hline
\end{tabular}

Differences were compared with one way analysis of variance. If $p<0.05$ followed by independent $t$ tests to compare baseline with diet and diet with rechallenge.

${ }^{*} \mathrm{p}<0.05$ one way analysis of variance.

$\mathrm{p}<0.05$
$t \mathrm{p}<0.05$ Student's $t$ test comparing baseline and end of diet.

$\mathrm{tp}<0.05$
$t \mathrm{p}<0.05$ Student's $t$ test comparing baseline and end of diet. $t$ test comparing end of diet and rechallenge.

fESR=erythrocyte sedimentation rate; $C R P=C$ reactive protein; $R F=$ rheumatoid factor; $E L I S A=$ enzyme linked immunosorbent assay. 


\section{Discussion}

Food is the greatest source of exposure to human antigens. ${ }^{17}$ There is ample evidence that allergens pass through the epithelium of the gastrointestinal tract, interact with the mucosal immune system, and gain access to the circulation. ${ }^{17}{ }^{18}$ In RA the permeability of the intestinal mucosa for allergens is increased. ${ }^{1923}$ It is unknown whether this is owing to the disease itself, to abnormal microbiological colonisation, or to commonly used non-steroidal antiinflammatory drugs. Up to now, there have been only vague indications that food allergens play any part in RA, in particular in rheumatoid factor negative RA. Nevertheless, the firm conviction of many patients and the unequivocal evidence of various case reports ${ }^{1-5}$ are sufficient grounds for the clinical investigation of the potentially aggravating role of food in RA. For as long as no single antigen can be incriminated, however, the design of reliable clinical studies will remain difficult.

The availability of two different artificial foods, almost identical in aspect and taste, but different in their content of milk allergens and azo dyes, ${ }^{17-24}$ enabled us to perform a controlled, double blind, randomised trial. Although both artificial foods differed in commonly incriminated foodstuffs, the control diet also eliminated most food allergens.

We studied rheumatoid factor seropositive $\mathrm{RA}$ because it seems to occur in a more homogenous group of patients than rheumatoid factor negative RA. In addition, rheumatoid factor positive RA is strongly associated with the genetically determined, human leucocyte antigen DR4, which apparently initiates specific immune responses when copresenting exogenic antigens to $T$ helper cells; this emphasises the possible role of exogenous antigens in rheumatoid factor positive disease. ${ }^{2526}$

The unattractiveness of the artificial foods limited the trial period to four weeks. Such a short trial period is uncommon, but the relatively rapid changes reported in previous studies support this study design. ${ }^{1-11}$

Although the effect of dietary manipulations might be better studied in the absence of drugs, we considered it unethical to withdraw both first and second line drugs in order to study a therapeutic manipulation that has not yet been proved to benefit patients with RA.

Considerable care was taken to ensure patient compliance during the 12 weeks of the study, and especially during the four week period of artificial feeding, regular support and instruction were provided by a specially assigned dietician. 14 is

The 116 selected patients were randomly allocated to one of the two diet groups. There were no statistically significant differences between the two groups. On average, however, the control group had slightly more active disease. This difference is not likely to have affected the results. Nearly all patients who completed this study showed some improvement of disease activity parameters while receiving one of the two artificial foods. As only subjective disease activity parameters changed significantly a placebo effect must be seriously considered. Another explanation might be energy malnutrition. ${ }^{27} 28$ Most patients lost weight during the diet period, despite the fact that the amount of food was individually adapted to the previous food intake. In part, these weight losses may be explained by diminished bowel content. As fasting is believed to influence disease activity it was tempting to assume that these decreased body weights were responsible for the observed improvements. ${ }^{27} 28$ No correlation was found, however, between losses of body weight and improvement of disease activity parameters $(r=0 \cdot 13)$. Changes in fat balance can influence autoimmune diseases, ${ }^{29}$ but both artificial foods contained normal amounts of fat (table 1). Diets poor in linoleic acid and rich in eicosapentaenoic acid can also influence disease activity, ${ }^{30-32}$ but the composition of our diets makes such an explanation unlikely (table 1). Deficiencies of certain vitamins and minerals are supposed to influence autoimmune diseases, ${ }^{30}{ }^{33}$ but the diets used contained normal amounts of all these requirements (table 1). The possibility that changes in bacterial flora during artificial feeding influenced our results should be considered seriously. ${ }^{21} 22$ 34-36 The lack of information on bacterial flora in our study makes it impossible to assess the role of this mechanism.

Although others have shown that milk allergens influence disease in individual patients, ${ }^{1-3}$ the results of our trial argue unequivocally against any short term effect of milk allergens or azo dyes in patients with rheumatoid factor positive RA, at least within the limits of measurement permitted by this study.

As indicated earlier, both foods had a very low content of potential allergens. The favourable effect of both artificial foods may, therefore, be due in part to allergy to one or more of the numerous food antigens other than lactoproteins and azo dyes.

Considerable differences were noted in the reactions of individual patients to the dietary manipulation. We arbitrarily selected nine patients with an overall improvement of more than $20 \%$ during allergen-restricted feeding followed by a deterioration of more than $20 \%$ (figure). All disease activity parameters in the nine marked responders showed clinically relevant improvement during the four week elimination of major food allergens. This was followed by an immediate and pronounced disease exacerbation after rechallenge. The resulting increase in disease activity with respect to baseline activity was reflected in all disease activity parameters (table 4). The immediate exacerbation during rechallenge together with the changes in objective parameters suggested that further, unidentified food intolerance might play a part among these nine marked responders. These patients were invited to participate in a subsequent double blind, placebo controlled study, rechallenging with specific foodstuffs against the background of an allergen free diet. ${ }^{37}$

Our results indicate that artificial food that eliminates most food allergens can have a beneficial effect on disease activity parameters in rheumatoid arthritis, which cannot be 
explained by energy deprivation. Placebo effects or changes in gastrointestinal bacterial flora may be partly responsible, but there are probably a minority of patients with food intolerance that significantly influences their RA.

We thank Mrs M Former-Boon, dietician, and Miss J M Nieuwenhuis, measurement technician, for their assistance, and Nutricia for their generous cooperation. This study was financially supported by a grant from 'het Praeventiefonds'.

1 Ratner D, Eshel E, Vigder K. Juvenile rheumatoid arthritis and milk allergy. $\mathcal{F} R$ Soc Med 1985; 78: 410-3.

2 Parke A L, Hughes G R V. Rheumatoid arthritis and food: a case study. BMF 1981; 282: 2027-9.

3 Panush R S, Stroud R M, Webster E M. Food induced (allergic) arthritis. Arthritis Rheum 1986; 29: 220-6.

4 Williams R. Rheumatoid arthritis and food: a case study. $B M \mathcal{F} 1981$; 283: 563 .

5 Lunardi C, Bambara L M, Biasi D, et al. Food allergy and rheumatoid arthritis. Clin Exp Rheumatol 1988; 6: 423-6.

6 Hicklin J A, McEwen L M, Morgan J E. The effect of diet in rheumatoid arthritis. Clinics in Allergy 1980; 10: 463

7 Darlington L G. Food allergy and rheumatoid disease. Ann Rheum Dis 1983; 42: 219.

8 Darlington L G. Does food intolerance have any role in the aetiology and management of rheumatoid disease? Ann Rheum Dis 1985; 44: 801-4.

9 Lunardi C, Pachor M L, Nicolis F, et al. Arthralgia, arthritis and food intolerance. Italian Fournal of Medicine 1987; 3: 88-91.

10 Felder $\dot{M}$, De Blecourt A C E, Wüthrich B. Food allergy in patients with rheumatoid arthritis. Clin Rheumatol 1987; 6: 181-4.

11 Beri D, Malaviya A N, Shandilya R, Singh R R. Effect of dietary restrictions on disease activity in rheumatoid arthritis. Ann Rheum Dis 1988; 47: 69-72.

12 Ropes M W, Bennett G A, Cobb S, Jacox R, Jessar R A. 1958 revision of diagnostic criteria for rheumatoid arthritis. Bull Rheum Dis 1958; 9: 175-6.

13 Steinbrocker $\mathrm{O}$, Traeger $\mathrm{C} \mathrm{H}$, Batterman R C. Therapeutical criteria in rheumatoid arthritis. $\mathcal{F} A M A$ 1949; 140: 659.

14 Panush R S, Carter R L, Katz P, Kowsari B, Longley S, Finnie S. Diet therapy for rheumatoid arthritis. Arthritis Rheum 1983; 26: 462-71.

15 Ziff M. Diet in the treatment of rheumatoid arthritis. Arthritis Rheum 1983; 26: 457-61

16 Ritchie D M, Boyle J A, McInnes J M, et al. Clinical studies with an articular index for the assessment of joint tenderness in patients with rheumatoid arthritis. $Q \mathcal{O F} \mathrm{Med}$ 1968; 37: 393-406.

17 Sampson H A, Buckley R H, Metcalfe D D. Food allergy. FAMA 1987; 258: 2886-90.

18 Walker W A, Isselbacher K J. Uptake and transport of macromolecules by the intestine, possible role in clinical disorders. Gastroenterology 1974; 67: 531-50.

19 Bjarnason I, Williams P, So A, et al. Intestinal permeability and inflammation in rheumatoid arthritis: effects of non-steroidal anti-inflammatory drugs. Lancet 1984; ii: non-ster $1171-3$.

20 Jenkins R T, Rooney P J, Jones D B, Bienenstock J, Goodacre $\mathbf{R} \mathrm{L}$. Increased intestinal permeability in patients with rheumatoid arthritis: a side-effect of oral nonsteroidal anti-inflammatory drug therapy? $B r \mathcal{F}$ Rheumatol 1987; 26: 103-7.

21 Gullberg R. Possible role of alterations of the intestinal flora in rheumatoid arthritis. Rheumatol Rehabil 1978; 17: 5-10.

22 Bennet J C. The infectious etiology of rheumatoid arthritis, new considerations. Arthritis Rheum 1978; 21: 531-8.

23 Zaphiropoulos G C. Rheumatoid arthritis and the gut. $\mathrm{Br} \mathcal{F}$ Rheumatol 1986; 25: 138-9.

24 Stevenson D D, Simon R A, Lumrey W R, et al. Adverse reactions to tartrazine. $\mathcal{J}$ Allergy Clin Immunol 1987; 78: 182-91.

25 Nepom G T, Byers P, Seyfried Ch, et al. HLA genes associated with rheumatoid arthritis. Arthritis Rheum 1989; 32: 15-21.

26 Gregersen P K, Silver J, Winchester R J. The shared epitope hypothesis. Arthritis Rheum 1987; 30: 1205-13.

27 Sköldstam L, Larsson L, Lindström F D. Effects of fasting and lactovegetarian diet on rheumatoid arthritis. Scand $\gamma$ Rheumatol 1979; 8: 249-55.

28 Sköldstam L. Fasting and vegan diet in rheumatoid arthritis. Scand F Rheumatol 1986; 15: 219-23.

29 Morrow W J W, Ohashi Y, Hall J, et al. Dietary fat and immune function: antibody responses, lymphocytes and accessory cell function in NZB $\times N Z W F_{1}$ mice. F Immunol 1985; 135: 3857 .

30 Homsy J, Morrow W J W, Levy J A. Nutrition and autoimmunity: a review. Clin Exp Immunol 1986; 65: 473-88.

31 Kremer J, Bigauoette J, Michalek A V, et al. Effects of manipulation of dietary fatty acids on clinical manifestations of rheumatoid arthritis. Lancet 1985; i: 184-7.

32 Kremer J M, Jubiz W, Michalek A, et al. Fish oil fatty acid supplementation in active rheumatoid arthritis. Ann Intern Med 1987; 106: 497-503.

33 Job C, Menkes C J, Delbarre F. Zinc sulfate in the treatment of rheumatoid arthritis. Arthritis Rheum 1980; 23: 1408-9.

34 Henrikson K, Uvnas-Moberg K, Nord C E, Johanson C Gullberg R. Gastrin, gastric acid secretion and gastric Gullberg R. Gastrin, gastric acid secretion and gastric microflora in patients with
Rheum Dis 1986; 45: 475-83.

35 Olhagen B, Mansson I. Intestinal Clostridium perfringens in rheumatoid arthritis and other collagen diseases. Acta Med Scand 1968; 184: 395-402.

36 Shinebaum R, Neumann V C, Cooke E M, Wright V Comparison of faecal florae in patients with rheumatoid arthritis and controls. Br $\mathcal{J}$ Rheumatol 1987; 26: 329-33.

37 van de Laar M A F J, Aalbers M, Bruins F G, van DintherJanssen A C H M, van der Korst J K, Meijer C J L M Food intolerance in rheumatoid arthritis, II. Clinical and histological aspects, Ann Rheum Dis 1992; 51: 303-6. 